\title{
GEOLOGICAL, STRUCTURAL AND RADIOACTIVITY STUDIES OF WADI SUTRAH- UMM GHEIG AREA, CENTRAL EASTERN DESERT, EGYPT
}

\author{
Khamees, H. ${ }^{1}$, Saad, H. R. ${ }^{2}$, El-Afandy, A. H. ${ }^{1}$, El-Tawapty, M. N. ${ }^{2}$, Khalil, M. M. ${ }^{2}$ \\ 1 Egyptian Nuclear Materials Authority, Cairo, Egypt \\ 2 Geology Dept., Faculty of Sciences, Damietta University, New Damietta, Egypt
}

\begin{abstract}
Wadi Sutrah-Umm Gheig area is located in the Central Eastern Desert, $20 \mathrm{~km}$ west of Marsa Alam international airport and $50 \mathrm{~km}$ south of the Quseir city. The area represents a part of the Arabian-Nubian Shield. It is also pertaining to the pan-African complex which consists of a folded belt of metasediments and metavolcanics subjected to greenschist-amphibolite facies metamorphism associated with partial melting of amphibolites and development of gneissic and migmatitic rocks. The rocks of the metasediments are tectonically enclosed sheets and lenses of serpentinites, forming an ophiolitic mélange. These rock units intruded by four granitoid groups related to different magmatic and tectonic events. The area was affected by three distinct deformational events $\left(\mathrm{D}_{1}-\mathrm{D}_{3}\right)$. $\mathrm{D}_{1}$ interpreted to have resulted from the closure of inter-arc basins, ophiolite obduction, and collision of East and West Gondwana, representing the earliest phase of deformation in the area. In the area of Umm Ghamis, $D_{1}$ represented by a series of tight overturned folds which have a NW-SE strike with NE and SW dip directions. During $\mathrm{D}_{2}$ transpression, which marked the terminal stages of the Pan-African Orogeny, along Wadi Sutrah a series of open folds with NW-SE trending axes that plunge mostly to the $\mathrm{SE}$. $\mathrm{D}_{3}$ deformation is thought to be belongs to the regional Najd system, represented by several prominent shear zones and strike-slip faults. The $F_{3}$ phase folds are trending nearly E-W discordant to the other older two phases $\mathrm{F}_{1}$ and $\mathrm{F}_{2}$.
\end{abstract}

Keywords: metasediments, metavolcanics, amphibolites, deformational events, obduction, collision, shear zone and folds

\section{INTRODUCTION}

The basement rocks of Egypt belongs to two different regimes, which are geologically unrelated, the older cycle of the basement exposed in the Western Desert as a part of the Sahara Metacraton, which underlie beneath the sedimentary cover in North Africa and the younger cycle of this complex is exposed around the Red Sea in the Eastern Desert and Sinai and is considered to be part of the Arabian-Nubian Shield (ANS). The ANS is the largest juvenile Neoproterozoic crust on the earth, which is formed as a result of the Mozambique Ocean closure during East African Orogen (EAO) (Fritz et al., 2013).

Sabet (1961) mapped the area of Jabal El Sibai including the northern part of the studied area and divided the exposed rock sequence into metasediments, metavolcanics, serpentinites, and talc-carbonates, granodiorites, younger granites, and trachyte necks. He also recorded some chromite lenses associating the serpentinites of Wadi Sutrah. Sabet (1961) appraise all the mafic rocks (volcanics, metasediments, and amphibolites) to be part of one supracrustal sequence.

El-Ramly and Akaad (1960) compiled a geological map covering the basement complex in the Central Eastern Desert (CED), including the present investigated area covered mainly by metasediments, gabbro, and granites. Kabesh and Refaat (1975) stated that Umm Naggat granitic stock west Kadabora area is of magmatic origin by using biotite as an index mineral in the petrogenesis of granites. They also concluded that the biotite of Umm Naggat stock is ferrous iron-rich varieties showing the uniformity of significant element composition.

Awadallah and Shaalan (1979) studied Jabal Mirier metavolcanics to the north of Kadabora. Three petrographical categories of rocks have been recognized: 1) dolerites or doleritic basalts; 2) hornblende schists, and 3) hornblende schists with relics of pre-existing dolerites. Also, their petrochemical studies 
Khamees, et al

revealed that basalts and dolerites are derived from magmas comparable with the average tholeiitic basalts.

Noweir (1983) studied and mapped the area around Wadi Umm Gheig. He reported that the area around Wadi Kab ar-rukab comprises mainly gabbro together with metagabbro, appenites and diabases.

The proposed structural model by El-Gaby et al. (1984) have a little support by the protolith age proposed for the gneisses in the emerging body which envolved new geochronological and isotope data (e.g., Andresen et al. 2009; Lie'geois and Stern 2010).

Rocks hosting the Banded Iron Formations (BIFs) in these areas and throughout the CED are of two types: (i) those described as "metasediments", "metamudstones", "metagreywackes", "metatuffs", or "meta pyroclastics" by different authors (e.g. Akaad et al., 1996; El Aref et al., 1993; Hamimi, 1988; Takla et al., 1999), and (ii) those described as "metavolcanics", which are predominantly basic to intermediate volcanic to hypabyssal rocks. In the southern outcrops of Umm Nar, El Imra, Gebel El Hadid, and Umm Ghamis, some of these rocks are foliated and described as "mafic, pelitic, quartzofeldspathic, and calcareous schists" by some authors e.g. (Hamimi, 1988; El Aref et al., 1993; Akaad et al., 1996; and El-Shazly and Khalil, 2014).The BIFs are volcanogenic in origin as indicated by their close spatial association with volcaniclastic rocks (El-shazly and Khalil 2016).

Fowler et al. (2007) conclouded that the gneissic association of diorite, tonalite and granite on both sides of Wadi Ash Shush represent a syn magmatically deformed tabular intrusion intruded into the island arc affined units. They considered the syn-kinematic Ash Shush tonalite to have been emplaced during this intrusion event which dated around 700-660 Ma based on $\mathrm{Pb} / \mathrm{Pb}$ ages by Bregar et al. (2002). This interpretation represent a conflict with the interpretations of most other workers, e.g. (El-Gaby et al.1984; Kamal El Din, 1993;Bregar et al., 2002; Fritz et al., 2002; Abd El Wahed, 2008 and Hamimi et al.,2019). The all argued that there is a tectonic break between the island arc affined metasupracrustal rocks and the orthogneisses. Bregar et al. (2002) divided these intrusives into (A) exhumation-related granites and (B) "late tectonic" granitoids depending on a combination of field relations and geochemical characteristics. Clearly post-dating the "late tectonic" granitoids are some gabbroic rock complexes, constituted of anorthosites, leucogabbros, alkaline granitoids, and diorites (Akaad and Abu El Ela 2002).

\section{Geological setting}

The detailed field description, the mutual field relations as well as the nature and types of contacts between these rocks have been carried out to be used in the mapping and structural analysis. The Landsat Thematic mapper and the high resolution world imagery are used as a field base over which all the geologic information and the contacts are traced. The chronological sequence of the exposed rock units is deduced from the field relations by surveying the contacts and determining their type and nature in more than one site (Fig. 1).

\section{Ophiolitic Mélange}

Ophiolitic mélange rocks are exposed at Wadi Umm Gheig, Wadi Umm Ghamis El Zarqa, Wadi Tanadib and also Wadi Sutrah. These rocks form separated bodies cropped associated with the metavolcanics in different locations and these bodies oriented parallel to their associated wadies. The ophiolitic mélange rocks in the study area, occupy a relatively small parts. The ophiolitic mélange rocks form a relatively low continuous hills and dissected ridges being traversed by wide tributaries (Fig. 1).

The ophiolitic mélange is the oldest rock unit in the studied area that covers about $25 \%$ of the total mapped area. It crops out in the northeastern and southeastern parts of the studied area as an elongated belt trending NNW-SSE along Wadi Sutrah and is intruded by the granitic rock of Umm Naggat pluton. This belt extends eastward and southward beyond the limits of the mapped area. The rocks are represented by different chaotic blocks and fragments of serpentinites and related rocks, metagabbros, and amphibolites, set in the metasedimentary mélange matrix which represented by metagreywakes, biotite schists, muscovite schists and hornblende schists. The ophiolitic matrix is fine to very fine grained, light greenish grey to very dark grey in colour and may attain black color as in graphite schists in the southern part of Wadi Sutrah. 


\section{Geological, structural and radioactivity studies of Wadi Sutrah}

This matrix is strongly deformed compared with the mélange blocks, being well foliated, lineated and folded. The ophiolitic fragments are of amphibolites, serpentinites, metagabbros and talc-carbonate rocks embedded within the metasedimentary mélange matrix (Fig. 2a-d). They generally form moderate to high topography, mostly elongated in an NNW-SSE direction.

Fig. 1. a) Location map of the area. b) Geologic map of the study area modified after EGPC/CONOC Coral (1987) and ElSayed et al. (2002).

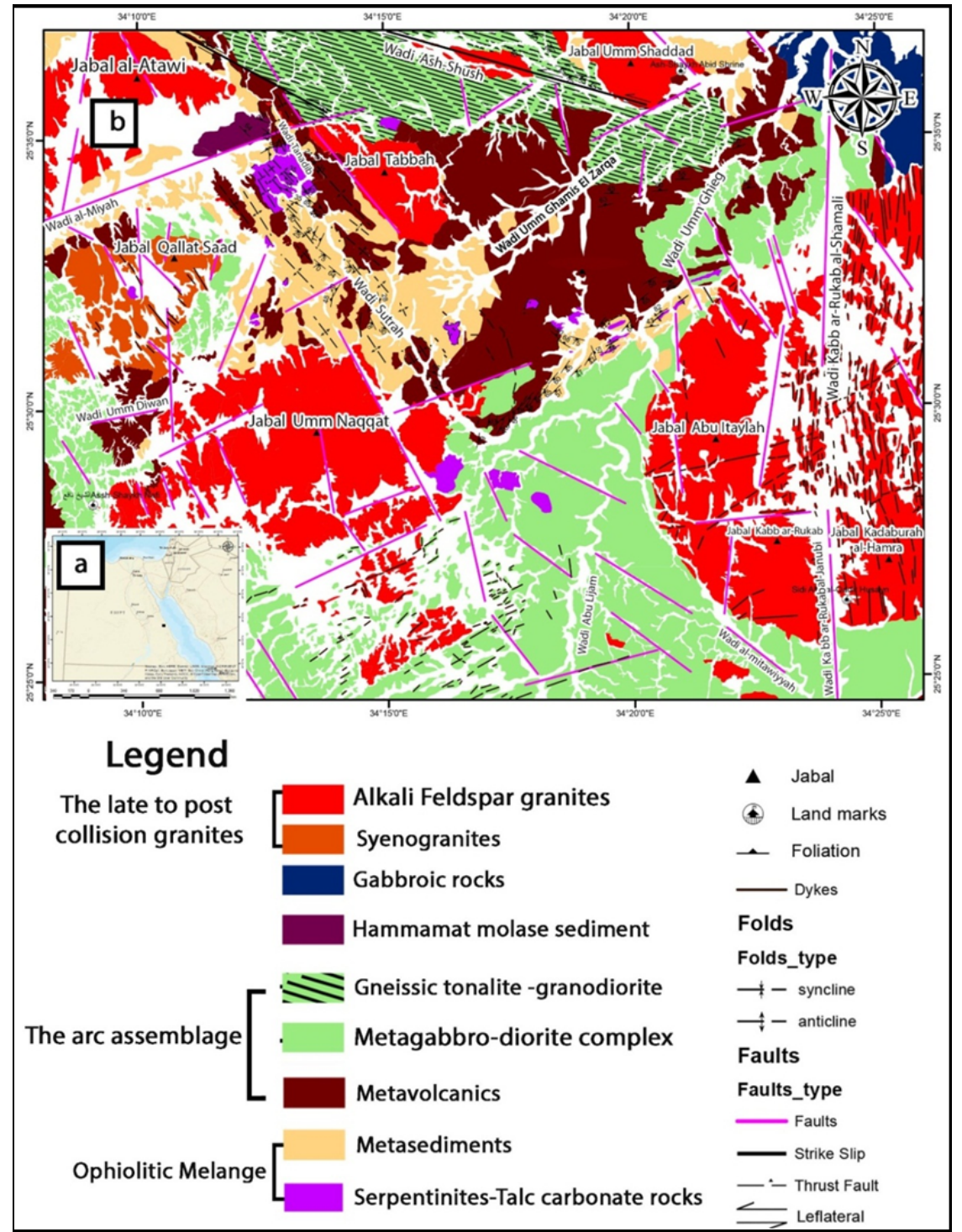

The ophiolitic blocks are irregularly distributed and range from pebble to mountain sizes, with common trend NW-SE direction. They show in all cases highly sheared tectonic contacts with the enclosing matrix. Throughout the study area, the matrix/blocks ratio is generally more than unity and varies from one place to another.

The serpentinite rocks are massive, fine-grained and greenish black to dark green and may attain lighter colors such as reddish brown, yellowish and whitish grey due to alteration to talc-carbonates. The talccarbonate rocks are generally foliated and have a cavernous appearance and predominate at the top of the ultramafic sheets. Sometimes the hillocks of serpentinites are found to be completely altered to talccarbonates. These rpentinites commonly occur in the northern part of Wadi Sutrah NE of the study area. Sometimes, they form lenticular bodies of various dimensions and steeply inclined concordant with the structure of the enclosing ophiolitic matrix.

Their contacts with the surrounding rock units are mostly faulted but sometimes, sharp contacts are observed. 


\section{Khamees, et al}

The metagabbros are predominant either as mountains with moderate to high topography or as a huge mass along the upper reaches of Wadi Umm Gheig southeast of the limited area to Wadi Abu Lijam to the east. They are intruded at its southwestern part by the older granitoids and sometimes-enclosed offshoots of Umm Naggat alkali granites. In their northern part, the metagabbros have tectonic contacts with the metavolcanics along Wadi Umm Gheig, whereas in their southern part they have sharp contacts with the muscovite granites in the extreme southern part of the study area. In their southern part, they are dissected by several basic dykes trending E-W direction. The metagabbros belt trends N-S, south of Wadi Umm Gheig, where they are affect by a major NW-SE fault, which separates the belt into two parts, this major fault extends north through Umm Naggat pluton. The metagabbros are deformed and show foliation of varying degrees of intensity. Several phases of deformation can be observed. In the southern part of the belt, the metagabbros are highly foliated.

The amphibolites are not common and found as small elongated masses which predominate at the southeastern part of Wadi Sutrah. They are highly foliated and the foliation is concordant with that of the surrounding metasediments. Petrographically, the serpentinite rocks are composed of one or more serpentine minerals. Antigorite is the most common with variable amounts of chrysotile and lizardite. Chromite is the most abundant accessory mineral beside chlorite, magnetite and hematite. The metagabbros are formed mainly of altered plagioclase, amphiboles and very little relics of pyroxene together with subordinate to accessory sphene, chlorite, epidote, carbonate, apatite and opaques. The amphibolites are fine-to medium-grained, composed of hornblende, plagioclase and quartz. Apatite, sphene and opaques are accessories.

\section{The arc assemblages}

The arc assemblage is represented by metavolcanics, metapyroclastics and arc granitoids. The metavolcanics crop out at different localities in the studied area, as discontinuous belts of low to moderate relief mountain ridges. They crop out at the northern part of the area at the entrance of Wadi Al Miyah, overlying the serpentinites of Wadi Sutrah. On the other hand, they are intruded by Umm Naggat granites and Jabal Qallat Saad younger granites. At the southwestern part, they are overlying the metagabbros and they also intruded by the older granitoids which send several offshoots into the metavolcanics and carry numerous xenoliths of them. They commonly show tectonic contacts with the older country rocks. The metavolcanics is characterized by the occurrence of BIF layers intercalated with the pyroclastic (Fig. 2e \& g). Generally, the metavolcanics are fine to very fine grained and display brown, green, or grey colours. They are mainly basic to intermediate in composition (metabasalts, metabasaltic-andesites and metaandesites), in addition with their equivalent pyroclastics.

The microscopic examination of the metabasalts revealed that these rocks consist mainly of micro phenocrysts of plagioclase and actinolite hornblende set in a finer holocrystalline groundmass of plagioclase, hornblende, sphene and epidote. Rare relics of augite are sometimes found. Chlorite, kaolinite, zoesite and sericite are the alteration minerals.

The metabasaltic-andesites are composed mainly of plagioclase, augite and hornblende. Iron oxides are accessory minerals. The meta-andesites are fine-grained, porphyritic and consist mainly of plagioclase phenocrysts set in a fine-grained groundmass formed of plagioclase, actinolite, chlorite and opaques. Chlorite, epidote and sericite are secondary minerals. The meta-pyroclastics are represented by an alternation of fine and coarse-grained crystal tuffs, which are composed of plagioclase and quartz fragments embedded in a fine-grained matrix of plagioclase, quartz, chlorite, biotite and opaques.

The arc granitoids in the studied area are represented by three masses with different sizes. They crop out in Wadi Al Miyah, Jabal Umm Gheig and Jabal Umm Ghamis El Zarqa in the northern part of the studied area. They constitute big size bodies, which invaded the surrounding country rocks composed of both the ophiolitic mélange and the metavolcanics. Field mapping and geological observations revealed that they are composed of a suite of igneous rocks ranging from quartz diorites-tonalites to granodiorites, which are massive rocks characterized by abundant joints and fractures. They form low relief hillocks, due to intensive weathering of these coarse-grained rocks, with smooth slopes and rounded tops. They have a light grey to whitish-grey color, coarse to medium-grained, and moderately to well foliated (Fig. 3b\&c). 


\section{Geological, structural and radioactivity studies of Wadi Sutrah}
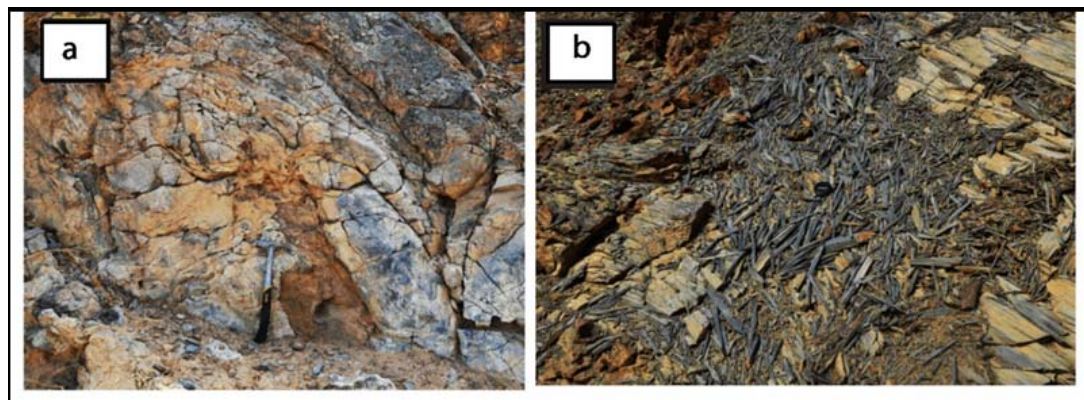
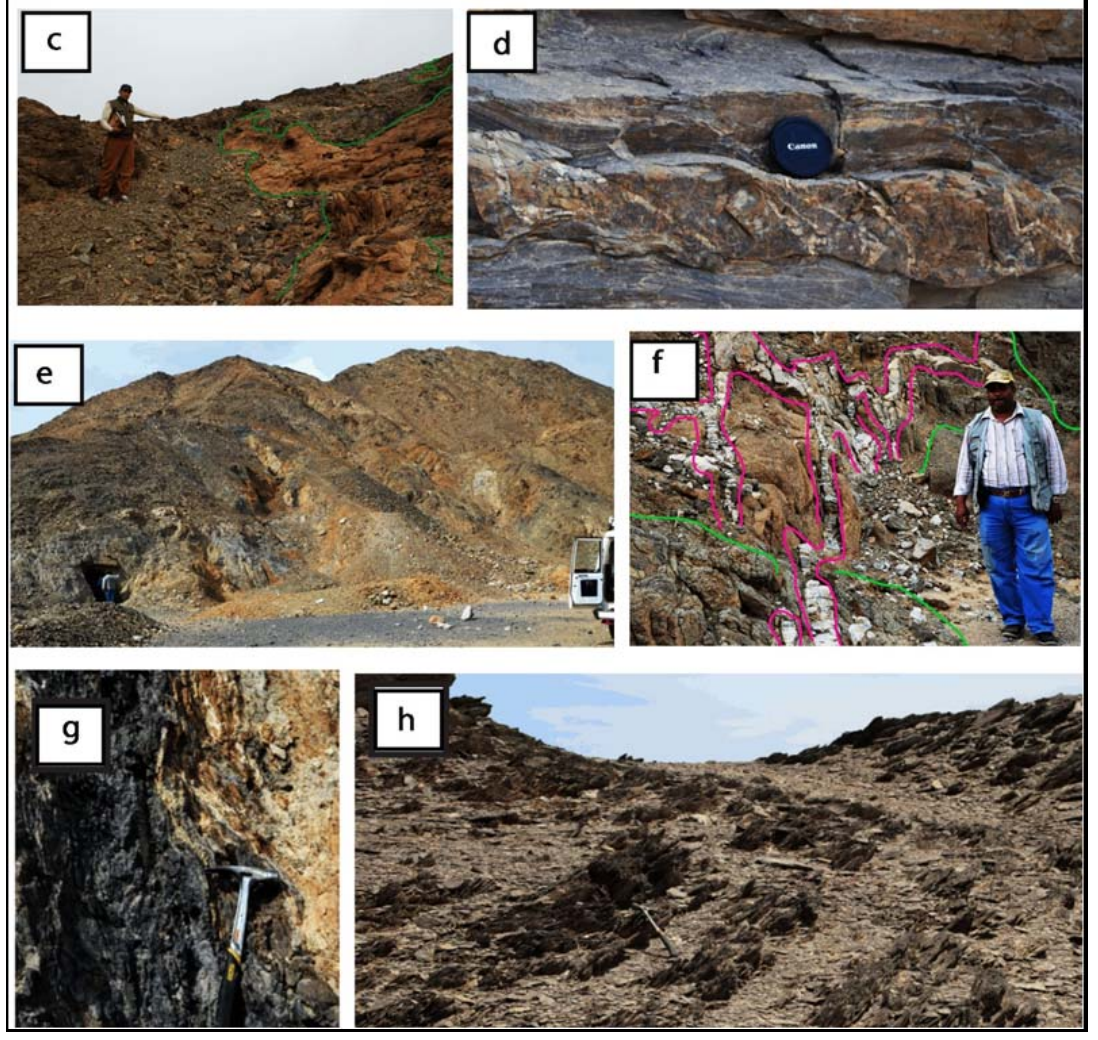

Fig. 2: Field photographs showing; (a) Serpentinites, (b) Pencil structure in graphite schist, (c) Cavernous talc carbonate rock in mélange matrix, (d) Boudins associated with Amphibolite, (e) Metavocanics with BIF layers, (f) Close up view showing acidic dikes network cutting through the metagabbro-diorite complex, (g) BIF intercalated with volcaniclastic metasediment, (h) Focus view of the tilted greywakes.

\section{Metagabbro-diorite Complex}

The intrusive metgabbro-diorite complex and granodiorites are well exposed along wadi Umm Diwan and Wadi Umm Gheig. At the southern parts of the study area, these rocks are well exposed along Wadi Abu Lijam, wadi Al-Mitawiyyah (Fig.1).

At Wadi Umm Gheig the rocks of metagabbro-diorite complex are rarely exposed in small scattered exposures. The metagabbro-diorite complex rocks are represented by melanocratic gabbros and diorites. The metagabbro has deep green to black color, medium to coarse grained, moderately weathered and slightly cut by veins of quartz and feldspars. The diorites are of light green color and brown weathered surface medium to fine-grained (Fig. $2 \mathrm{f}$ ).

\section{Gneissic Tonalite-Granodiorites}

These rocks cover a large region at the northern part of the area. The gneissic rock belt is located to the north of the metavolcanics, to the east of Jabal Al-Atawi, to the west and south of Jabal Umm shaddad. They are well exposed along Wadi Ash-Shush and its northern and southern tributaries (Fig. 1).

The gneissic tonalite-granodiorites is characterized by low topographic, moderate to highly weathered hills at the end of Wadi Ash-Shush which suffered abrupt topographic change as representing the southern part of El Sibai core complex. The gneissic tonalite-granodiorites have a light grey to whitish-grey color, coarse to medium-grained, and moderately to well foliated (Fig. 3a-c). 


\section{Khamees, et al}

The tonalites are inhomogeneous in grain size and have a wide range of colour ranging from a whitish grey to light pink. Microscopically, they are composed mainly of plagioclase, quartz, and hornblende. Kfeldspar occurs as minor constituent not exceeding $5 \%$ of the total amount of the feldspars. Minor amounts of biotite are observed in some samples.

The granodiorites are grey to dark grey in color, medium to coarse grained. Microscopically, they are hypidiomorphic with poikilitic and myrmekitic textures. They are mainly composed of plagioclase and quartz together with subordinate microcline, biotite and hornblende.

\section{Hammamat Sediments}

Hammamat sediments have a limited distribution in the study area where these sediments are only recorded at north western part of the map. The Hammamat sediments are cropping out at Jabalal-Atawi basin and at wadi Tanadib (Fig.1).

More than one sedimentary cycle is noticed each start with very coarse-grained conglomerates and end with relatively finer greywacke sand-siltstones. Primary sedimentary structures are hardly distinguished. The second conglomerates contain a moderately sorted and angular to subrounded volcanics, dioritic and granitic pebbles (Fig. $2 \mathrm{~h}$ ).

Fig. 3: Field photographs showing; (a) Panoramic view of the Ash Shush showing the contact between gneissic tonalite-granodiorite and the metavolcanics, (b) Focus view on Wadi Ash Shush granodiorite showing the alignment of the mafic minerals, (c) Focus view on Wadi Ash Shush tonalite showing the roding of it as a result of NW strike slip fault, (d) Panoramic view of the contact between the Kadabora granite and the metagabbro-diorite complex (e) Panoramic view of the contact between the Umm Naggat granite and the Metavolcanics
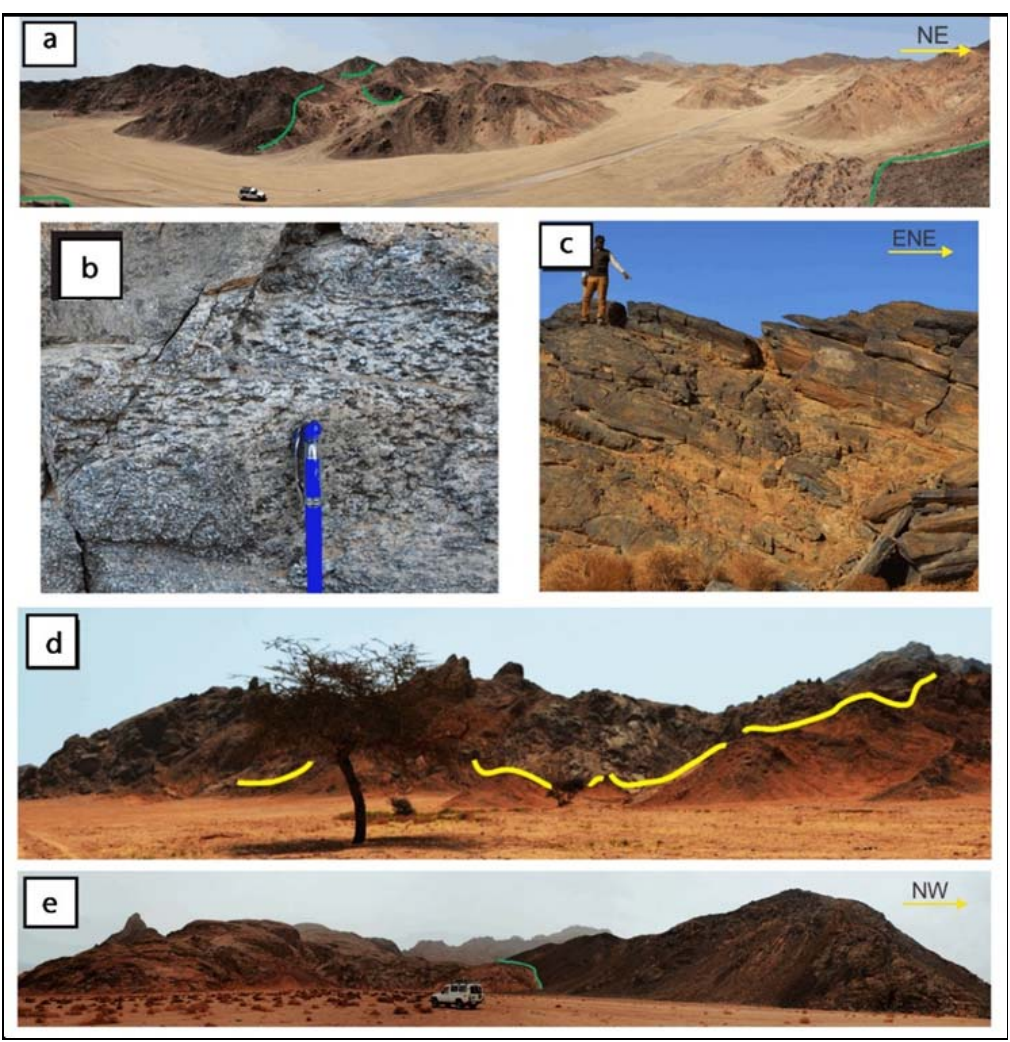

\section{The late to post-collision granites}

They are the most predominant rocks in the area of study. They occupy more than $40 \%$ of its surface exposures and are characterized by their high topography forming the highest topographic features in the studied area, namely Jabal Umm Naggat, Jabal Kadabora, Jabal Al Atawi, and Jabal Umm Shaddad. They intrude all the previously described older rocks with typical intrusive contact. The younger granites are characterized by exfoliation, cavernous and bouldery appearance. Also, they are characterized by the welldeveloped joint surfaces in some areas and at least one significant set of joints could be found either steeply inclined or sometimes vertical. The younger granites are classified in the area to; syenogranites and alkali feldspar granites. 


\section{Geological, structural and radioactivity studies of Wadi Sutrah}

The syenogranites crop out in Jabal Qallat Saad, small parts in the central part of Jabal Umm Naggat, and Jabal Kadabora which form an elliptical shaped mass oblated in the E-W direction. The syenogranitesin the studied area are epizonal and unfoliated mass. These granitic masses have sharp intrusive contacts steeply dipping with the surrounding country rocks. The syenogranites send offshoots and apophyses into all the surrounding rocks. Also, the syenogranites crop out in the extreme western part of the studied area. They form scattered moderate relief, and deeply eroded hillocks. These granites are highly fractured and jointed, medium to coarse-grained whitish to pinkish yellow in color. They are characterized by intense weathering and alteration. They also occurred as small isolated outcrop with highly sheared and steeply dipping foliation.

The northern part of Umm Naggat biotite granites has suffered extensive post-magmatic metasomatic reworking results in the development of albite-enriched and greisenized granites of about $600 \mathrm{~m}$ thick, and more than $3 \mathrm{~km}$ in the strike length.

The syenogranites are medium to coarse grained, holocrystalline and of equigranular texture. They are mainly composed of alkali feldspar (mainly microcline, orthoclase), quartz, plagioclase, muscovite and minor amounts of biotite, apatite and opaques.

The alkali feldspar granites crop out at the northern parts of Jabal Umm Naggat (Fig. 3 e) and Jabal Kadabora, northeastern and northwestern parts of the studied area in Jabal Umm Shaddad, Jabal Tabbah and Jabalal-Atawi. They form conspicuous mountain ridges (Fig. $3 \mathrm{~d}$ ). They show sharp intrusive contacts the surrounding rocks. The alkali-feldspar granites are affected by a sinistral strike-slip fault with a N-S direction resulting in splitting the mass of Jabal Al-Atawi and Jabal Umm Shaddad into two separate parts, having a general elongation in the E-W direction. They are medium to coarse-grained, exfoliated and highly weathered with pinkish red color due to staining with iron oxides.

The alkali feldspar granites are leucocratic, medium to coarse- grained. They are hypersolvus composed of K-feldspars (perthites, orthoclase perthites, and antiperthites), quartz and mica.

Post-granite basic, intermediate and acidic dykes are frequently observed crossing the granitic plutons. The dyke swarms are generally run in parallel to subparallel sets. According to their field relations, they can be chronologically arranged from older to younger as; Acidic dikes which include granite, felsites, rhyolites, and granophyres and Basic dikes which include basalts and dolerites. They are massive, fine grained and unfoliated rocks. These dykes have a general E-W trend and show sharp contacts with the enclosing rocks. Post Pan-African trachyte plugs occur in the central southern part of Umm Naggat pluton. They are massive, fine-grained and their color varies from creamy to brownish yellow.

\section{Structural elements and analysis}

The study of the structure features of the study area aims to clarify the sequence of phases sequences of deformation affecting the different rock units and to characterize the trends and styles of structures associated with each phase. The different structural elements are checked on various exposures, recorded and plotted on the landsat image (TM) that used as a base map during the field work. The collected field data are projected on the geologic map which represents the distribution of major and some minor structural elements that affected the ophiolitic mélange, metavolcanics and the mylonitized granodiorites.

The primary structures in the ophiolitic mélange rocks and the metavolcanics are suffered from the subsequent phases of deformations, metamorphism and the intrusion of granitic rocks. The only primary feature recorded is the bedding or layering (S0) which is detected as alternation of different types of schists as well as the inter-layering between volcanic flows and pyroclastics (Fig. 4 a-c). On the other hand, the Hammamat sediments show clear and well-preserved primary structures such as; bedding, graded bedding and cross bedding (Fig. 2h). Some primary structures in the metavolcanics are recorded such as banding and layering in their pyroclastics (Fig. 2g).

The planar and linear fabric elements are, somehow, preserved in the deformed rocks as well as different types of lineations and minor fold axes (Fig. 3b and 4 d-f). Subsequent brittle deformation represented by major and minor faults, fractures and joints remarkably affects the different rock types. 


\section{Khamees, et al}

The deformed rocks in the study area are preserved in two strain states as a result for the stresses causing the deformation (ductile and brittle deformation states). These two types of deformation produce the major and minor folds, the different types of foliations and lineations as well as faults, shear zones, fractures and joints.

Folds are clearly seen and well-illustrated in the ophiolitic mélange rocks, metavolcanics as well as the Hammamat sediments. The fold styles present are varying from open gentle folds to tightly appressed overturned and recumbent folds and in dimensions from microscopic scale to folds that extend few kilometers along their axial planes (Fig. 4 a \& b).
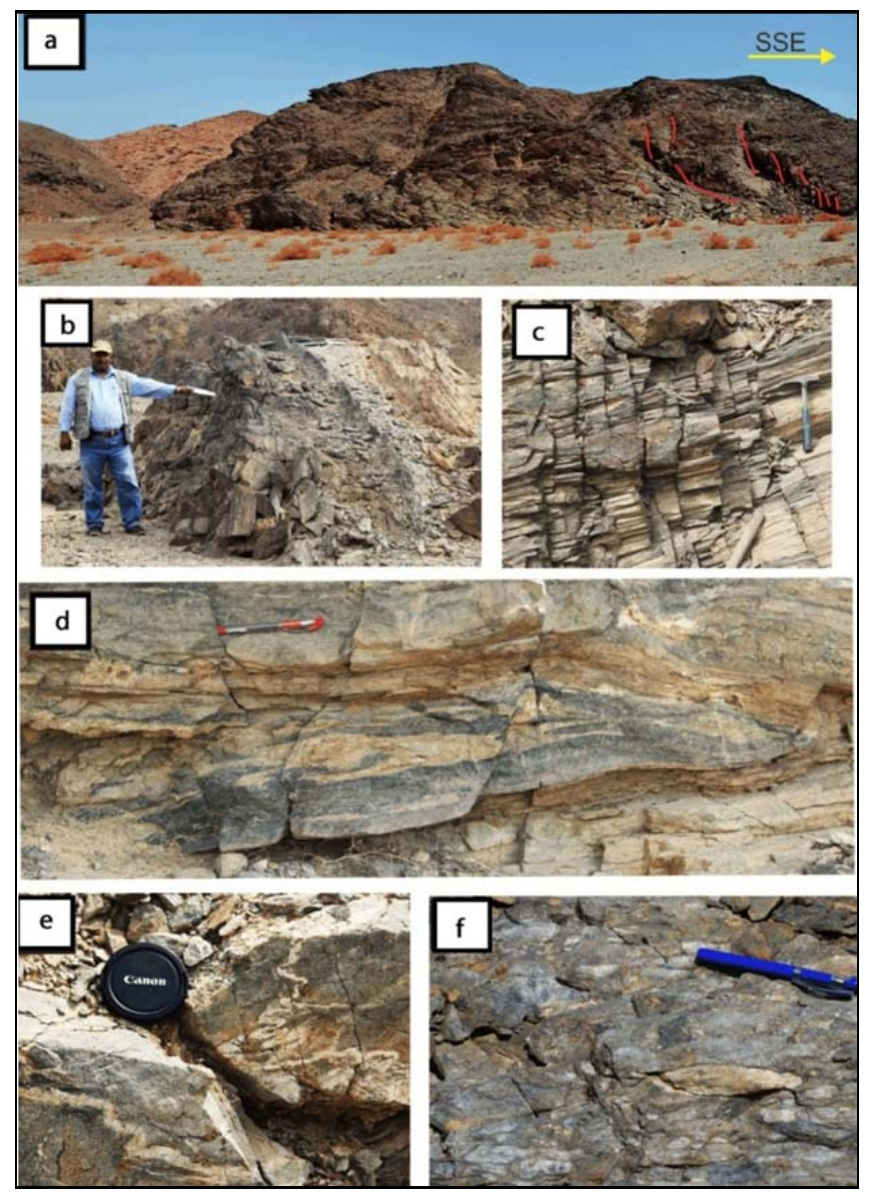

Fig. 4: Field photographs showing; (a) Panorma of anticline fold limb related to F2, (b) Close up view for nearly symmetrical mesoscopic anticline fold on ophiolitic metasediments (note limbs direction) related to F2, (c) Cleavages nearly perpendicular to the foliation planes in metasediment, (d) Inter folial fold (F1) (recumbant) in amphibolites schist, (e) Ptygamtic fold in Qz vein within Um Ghamis amphibolite, (f) Stretched pebbles in Hammamat sediments.

The major folds recorded in the ophiolitic mélange are in Wadi Tanadib, Wadi Sutrah and at Wadi Umm Ghieg. Wadi Tanadib folds are found as a fold system of adjacent anticline and syncline of the ophiolitic me'lange and with NW-SE trending curved axial planes and plunging toward southeast.

Minor folds are seen with remarkable abundance in the rock domains occupied by the ophiolitic mélange. These folds vary from few centimeters to few meters. They are of variable trends, styles and show the complex relations of superimposed folding and refolded folds that indicate successive deformation and give a clue to the multiphase deformation affecting the area. These folds recoded at Wadi Tanadib and represents F1 folds associated with and enclosed within the ophiolitic me'lange matrix. Also present at Wadi Umm Ghieg as Ptygamtic and interfolial folds associated with the amphibolite rocks (Fig. $4 \mathrm{~d} \& \mathrm{e})$. We used here the methods which considered the homogeneity in the different types of structural elements methods of (Turner and Weiss, 1963 and Ramsay, 1967)(Fig. 5).

Domain A represents Al-Atawi basin sediments which occupied mainly by silt and grey wakes of relatively moderate tilting and dissected by several cleavages resulting in formation of pencil structures. The stereographic plot of lineations shows a maximum concentration on (plunge, bearing) $=21^{\circ}, 327^{\circ}$. 


\section{Geological, structural and radioactivity studies of Wadi Sutrah}

This concentration fitted with the pole to the girdle of the bedding with best fit great circle (strike, dip $\mathrm{RHR})=53^{\circ}, 74^{\circ}$.

Domain BandC represents the ophiolitic mélange of Wadi Tanadib and Wadi sutrah. It is mainly occupied by the different varieties of schists like hornblende-biotite schists, tremolite schists and some quartzites. The stereographic plotting of the pole to the $\mathrm{S} 0 / / \mathrm{S} 1$ foliation forms a great girdle Best fitted at $222^{\circ}, 85^{\circ}$ and $041^{\circ}, 81^{\circ}$ respectively. These poles matched the maximum concentration of $18^{\circ}, 131^{\circ}$ and $8^{\circ}, 315^{\circ}$ of the The stereographic plotting for lineations which related here to L2.

Domain DandF represents the ophiolitic mélange at the juncture of Wadi sutrah and Wadi Umm Gheig for $\mathrm{D}$ and at almost the middle of Wadi Umm Gheig for F. It is mainly occupied by the different varieties of schists like hornblende-biotite schists, tremolite schists, Amphibolites and some quartzites. The stereographic plotting of the pole to the S0//S1 foliation forms a great girdle Best fitted at $176^{\circ}, 58^{\circ}$ and $181^{\circ}, 48^{\circ}$ respectively. These poles matched the maximum concentration on $7^{\circ}, 9^{\circ}$ and $44^{\circ}, 55^{\circ}$ of the The stereographic plotting for lineations which related here to the third phase of deformation.

Fig. 5: Planar fabrics and lineation data in the area.( A) for al-Atawi basin, (B \& C) for F2 folds at WadiSutrah, (D to $\mathrm{H})$ for the fabrics along Wadi Umm Gheig, and finally (I) for Wadi Ash-Shush.

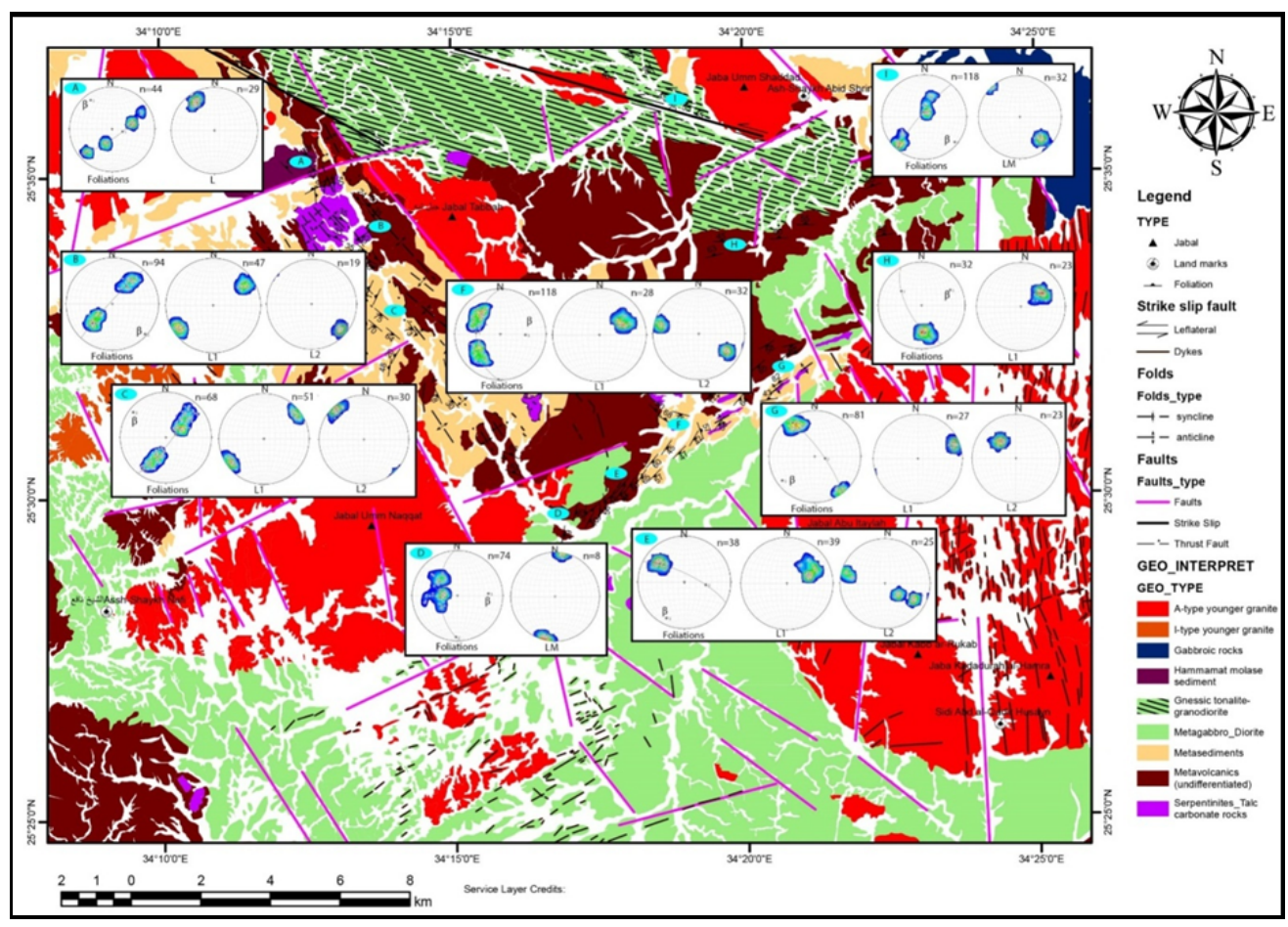

Domain E, G and H represents the ophiolitic mélange and the metavolcanics of Umm Ghamis El Zarqa at Wadi Umm Gheig and the south-east end of Wadi Ash-Shush. It is mainly occupied by the different varieties of schists, Amphibolites and volcaniclastic metasediments. The stereographic plotting of the pole to the $\mathrm{S} 0 / / \mathrm{S} 1$ foliation forms a great girdle Best fitted at 296,$75 ; 323^{\circ}, 77^{\circ}$ and $151^{\circ}, 64^{\circ}$ respectively. These poles matched the maximum concentration on $16^{\circ}, 40^{\circ}$ and $18^{\circ}, 69^{\circ}$ and $44^{\circ}, 59^{\circ}$ of the The stereographic plotting for lineations which related here to L1.

Domain I represented in Wadi Ash-Shush Gneissic Tonalite- Granodiorite. The stereographic plot of lineations shows a maximum concentration of $29^{\circ}, 136^{\circ}$. This concentration fitted with the pole to the girdle of the mylonitic foliations with Best fit great circle $219^{\circ}, 82^{\circ}$.

\section{Radioactivity}

A total number of 72 rock samples representing the different rock types were collected, to study the distribution patterns of $U$ and Th. These samples include: serpentinites, (3samples), metagabbros, (10 samples), arc-metavolcanics, (9 samples), arc-granitoids, (11 samples), and younger granites, (16 samples). In addition, 32 anomalies samples were collected to study $U$ and Th distribution in the hydrothermally altered zones. 


\section{Khamees, et al}

The $\mathrm{U}$ contents of the serpentinites range from 0.14 to $0.39 \mathrm{ppm}$ with an average of $0.25 \mathrm{ppm}$. The Th contents range from 0.86 to $1.23 \mathrm{ppm}$ with an average of $0.96 \mathrm{ppm}$. The $\mathrm{U}$ and Th contents of the serpentinites in the studied area are higher than the published data for the ultrabasic rocks of Dahlkamp (1993).

The $U$ contents of the metagabbros range from 0.5 to $1.73 \mathrm{ppm}$ with an average of $2.05 \mathrm{ppm}$. The Th contents range from 2.36 to $11.31 \mathrm{ppm}$ with an average of $4.49 \mathrm{ppm}$ (table 6.2). The average contents of $\mathrm{U}$ and Th of the metagabbros are similar to the average contents of the intrusive basic rocks of Adams et al., (1959).

The $U$ contents of the metabasalts $(0.96-2.10 \mathrm{ppm})$ with an average $(1.40 \mathrm{ppm})$ is within the range of basic effusives $(0.2-4 \mathrm{ppm})$ and the Th contents range from $(1.18-6.25 \mathrm{ppm})$ with an average $(3.10 \mathrm{ppm})$ is within the range of basic effusives (0.1-10 ppm) of Adams et al., (1959). The U contents in the metaandesites are (1.05-2.19 ppm) with an average $(1.52 \mathrm{ppm})$ is within the range of intermediate extrusives (0.8-3 ppm) of Dahlkamp, (1993).

Table 1: $\mathrm{U}$ and $\mathrm{Th}$ contents, $\mathrm{Th} / \mathrm{U}$ ratio and their averages of the studied rocks

\begin{tabular}{|c|c|c|c|c|c|c|c|}
\hline Rock Type & No, of Readings & \multicolumn{2}{|c|}{$\mathrm{U}(\mathrm{ppm})$} & \multicolumn{2}{|c|}{ Th (ppm) } & \multicolumn{2}{|c|}{$\mathrm{Th} / \mathrm{U}$} \\
\hline Serpentinite & & Min. & Max. & Min. & Max. & Min. & Max \\
\hline & 3 & 0.14 & 0.39 & 0.68 & 1.23 & 3.15 & 4.5 \\
\hline Average & & \multicolumn{2}{|c|}{0.25} & \multicolumn{2}{|c|}{0.96} & \multicolumn{2}{|c|}{3.8} \\
\hline Metagabbro & 10 & 0.47 & 1.73 & 2.88 & 4.84 & 2.12 & 6.31 \\
\hline Average & & \multicolumn{2}{|c|}{2.05} & \multicolumn{2}{|c|}{4.49} & \multicolumn{2}{|c|}{2.19} \\
\hline Metabasalt & 6 & 0.96 & 2.19 & 1.18 & 6.25 & 1.51 & 3.6 \\
\hline Average & & \multicolumn{2}{|c|}{1.4} & \multicolumn{2}{|c|}{3.1} & \multicolumn{2}{|c|}{2.21} \\
\hline Metaandesite & 3 & 1.05 & 2.19 & 2.51 & 5.72 & 2.61 & 4.03 \\
\hline Average & & \multicolumn{2}{|c|}{1.52} & \multicolumn{2}{|c|}{4.53} & \multicolumn{2}{|c|}{2.98} \\
\hline Tonalite & 8 & 2 & 3.92 & 2.76 & 5.33 & 135 & 3.32 \\
\hline Average & & \multicolumn{2}{|c|}{2.60} & \multicolumn{2}{|c|}{4.24} & \multicolumn{2}{|c|}{1.80} \\
\hline Granodiorites & 3 & 1.07 & 2.62 & 2.77 & 5.59 & 2 & 5.09 \\
\hline Average & & \multicolumn{2}{|c|}{1.65} & \multicolumn{2}{|c|}{4.53} & \multicolumn{2}{|c|}{3.08} \\
\hline Syenogranites & 3 & 1.74 & 2.85 & 5.04 & 6.15 & 1.7 & 8.31 \\
\hline Average & & \multicolumn{2}{|c|}{1.99} & \multicolumn{2}{|c|}{5.462 .74} & & \\
\hline Alkali Fel. Gran & 4 & 1.81 & 6.09 & 8.07 & 11.31 & 1.85 & 10.3 \\
\hline Average & & \multicolumn{2}{|c|}{3.6} & \multicolumn{2}{|c|}{9.06} & \multicolumn{2}{|c|}{2.5} \\
\hline Anom. samples & 32 & 15 & 506 & 16 & 713 & 103 & 3.6 \\
\hline Average & & \multicolumn{2}{|c|}{220} & \multicolumn{2}{|c|}{313} & \multicolumn{2}{|c|}{1.55} \\
\hline
\end{tabular}

The $U$ contents of the quartz diorites range from 0.83 to $3.92 \mathrm{ppm}$ with an average of $2.49 \mathrm{ppm}$, while the thorium contents range from 3.69 to $5.33 \mathrm{ppm}$ with an average of $4.24 \mathrm{ppm}$. The $\mathrm{Th} / \mathrm{U}$ ratios range from 1.23 to 3.32 with an average of (1.80). The U contents of the granodiorites range from 1.07 to 2.62 ppm with an average of $1.65 \mathrm{ppm}$, and the Th contents range from 2.77 to 5.59 with an average of 4.53 $\mathrm{ppm}$. The $\mathrm{Th} / \mathrm{U}$ ratios range from 2.16 to 5.09. The average contents of $\mathrm{U}$ and $\mathrm{Th}$ of the arc-granitoids are similar to the average contents of quartz diorites and granodiorites of Clark et al. (1966) and Rogers and Adams (1969).

The $\mathrm{U}$ contents of the late to post-collision granites range from 1.10 to $14.02 \mathrm{ppm}$ with an average of 3.6 for the alkali feldspar granites, 1.99 for muscovite granites and $5.83 \mathrm{ppm}$ for the biotite granites. The Th contents range from7.67 to $58.1 \mathrm{ppm}$ with an average of 9.03 for the alkali feldspar granites, 5.46 for muscovite granites and $10.53 \mathrm{ppm}$ for the biotite granites. The comparison of the late to post collision granites with the reported ranges and averages of Clark et al. (1966), Rogers and Adams (1976) and Adams et al., (1969), shows that the studied granites of Um Naggat area are higher in uranium relative to the normal contents of thorium, which explain the low average $\mathrm{Th} / \mathrm{U}$ ratios observed.

From the previous discussions, we can conclude that the studied area is poor in radioelements except the northern part of the biotite granite mass of Um Naggat and Kadabora granitic masses which could be classified as relatively uranium rich granites, where uranium contents are exceeding twice the Clarke value. 


\section{Geological, structural and radioactivity studies of Wadi Sutrah}

In spite of that, no appreciable concentration of U-minerals has been so far detected in the granitic masses or elsewhere. This may suggest the existence of $U$ in the resistate minerals such as zircon, sphene and apatite as well as columbite, samarsakite and thorite minerals.

\section{CONCLUSIONS}

Wadi Sutrah-Umm Gheig area located in the Central Eastern Desert, occupies an area of about $588 \mathrm{~km}^{2}$ of the pan-African nappe complex consists of older metasediments and metavolcanics. They, tectonically enclose sheets and lenses of serpentinites, forming an ophiolitic me'lange. These rock units are intruded by four granitoid types (Tonalites, Granodiorites, syenogranites and alkali feldspar granites). It also has a distinct and significant three different dike groups.

From the domains map and the accompanied contoured point diagrams that representing the $\mathrm{S}_{0} / / \mathrm{S}_{1}$ foliation, $\mathrm{L}_{1}$ lineation and $\mathrm{L}_{2}$ lineation it can be concluded that the overall structure of the study area is represented by a huge antiform (anticline fold) whose axis is trending NNW-SSE and its western limb is Wadi Sutrah and while its eastern limb is Wadi Umm Gheigh.

This is well represented by the $\mathrm{S}_{0} / / \mathrm{S}_{1}$ foliation contour point diagrams in the various domains where the domains $\mathrm{A}, \mathrm{B}, \mathrm{C}$ representing the western limb of the huge antiform and the foliations in them nearly have a NW-SE strike with NE and SW dip directions.

Domain D and F represent the hinge zone of the antiform where the foliations nearly have E-W strike and North and South dip. Domain E, G and H represent the eastern limb of the megascopic antiform, where the foliations have a NE-SW strike and dipping towards NW and SE.

The huge or the megascopic antiform that represent the whole structure of the area is the product of both $F_{1}$ and $F_{2}$ Co-axial phases of deformation where the minor $F_{1}$ intrafolial folds represent $F_{1}$ phase while the major antiform which incorporating them along its limbs representing $F_{2}$. The major thrusts of the NW-SE trend are also pertaining to the $\mathrm{F}_{2}$ phase.

Domain I is considered a unique one where it is covered by the gneissic tonalite- granodiorite of Wadi Ash-Shush and its fabric elements are similar to that of domain A, B and C but with mylonitic folaitions. It is affected by the last and third $\mathrm{F}_{3}$ phase that affecting the area and is mainly associated the sever strike slip movements exemplified by El Shush shear zone. The $\mathrm{F}_{3}$ phase folds are trending nearly E-W discordant to the other older two phases $\mathrm{F}_{1}$ and $\mathrm{F}_{2}$.

The area is poor in radioelements except the northern part of the biotite granite mass of Um Naggat and Kadabora granitic masses which could be classified as relatively uranium rich granites, where uranium contents are exceeding twice the Clarke value. In spite of that, no appreciable concentration of U-minerals has been so far detected in the granitic masses or elsewhere. This may suggest the existence of $U$ in the resistate minerals such as zircon, sphene and apatite as well as columbite, samarsakite and thorite.

\section{REFERENCES}

Adams, J. A., Osmond, J. K., and Rogers, J. J. (1959): The geochemistry of thorium and uranium. Physics and Chemistry of the Earth, 3, 298-348.

Akaad, M., Noweir, A., and Abu El Ela. A., (1996): Geology of the Pan-African basement rocks of the Jabal Alhadid-Wadi Mubarak district, Eastern Desert, Egypt. Geol. Surv. Egypt, Paper (73):78.

Akaad, M., and El Ela, A. A. (2002): Geology of the basement rocks in the Eastern half of the belt between latitudes $25^{\circ} 30^{\prime}$ and $26^{\circ} 30^{\prime} \mathrm{N}$ Central Eastern desert, Egypt: covering parts of sheets NG $36 \mathrm{~K} 2, \mathrm{~K} 3$, L1 and NG 36 G5, G6, H4. Geol. Surv. Egypt.

Ali, K., Stern, A., Manton, R. J., Kimura, W. I., and Khamees, H. A. (2009): Geochemistry, Nd isotopes and $\mathrm{U}-\mathrm{Pb}$ SHRIMP zircon dating of Neoproterozoic volcanic rocks from the Central Eastern Desert of Egypt: New insights into the 750 Ma crust-forming event. Precamb. Res., 171(1-4), 1-22.

Andresen, A., Augl, L., Boghdady, G., Lundmark, A., Elnady, O., Hassan, M. and El-Rus. M. A. (2010): Structural constraints on the evolution of the Meatiq gneiss dome (Egypt), east-African orogen.J. Afr. Earth Sci., 57(5):413-422. 
Khamees, et al

Awadallah, M. F. and Shaalan, M., (1979): Petrochemical and geochemical studies on Jabal Mirier metavolcanics, Central Eastern Desert, Egypt. Chem. Geol., 26(1-2):65-75.

Bregar, M., Bauernhofer, A., Pelz, K., Kloetzli, U. Fritz, H., and Ummayr., P. Ne (2002): Alate Neoproterozoic magmatic core complex in the Eastern Desert of Egypt: emplacement of granitoids in a wrench-tectonic setting. Precamb. Res., 118(1-2):59-82.

Clark, R. S., Rowe, M. W., Ganapathy, R., and Kuroda, P. K. (1967): Iodine, uranium and tellurium contents in meteorites. Geochem. et Cosmochem. Acta, 31(10), 1605-1613.

Dahlkamp, F. J. (1993): Geology of the uranium deposits, 460.

El Aref, M., El Dougdoug,, A., Wahed, M.A., and El Manawi., A. (1993): Diagenetic and metamorphic history of the Umm Nar BIF, Eastern Desert, Egypt. Mineralium Deposita, 28(4):264-278.

El-Gaby, S., El-Nady, O., and Khudeir., A. (1984): Tectonic evolution of the basement complex in the Central Eastern Desert of Egypt. Geol. Rdsch., 73(3):1019-1036.

El-Naby, H. A., and Frisch. W., (2002): Origin of the Wadi Haimur-Abu Swayel gneiss belt, South Eastern Desert, Egypt: petrological and geochronological constraints. Precamb. Res., 113(3-4): 307-322.

El-Ramly, M. and Akaad, M. (1960): The basement complex in the CED of Egypt between lat. 24.30 and $25 \circ 40$ n. Geol. Surv. Egypt, 8:33.

El-Sayed, M., F. M, Furnes, H. and Kanisawa. S. (2002): Geochemistry and petrogenesis of the Neoproterozoic granitoids in the Central Eastern Desert, Egypt. Chemie der Erde, 62(4): 317-346.

El-Shazly, A. K., and Khalil, K. I. (2014): Banded iron formations of Umm Nar, Eastern Desert of Egypt: P-T-X conditions of metamorphism and tectonic implications. Lithos, 196, 356-375.

El-Shazly, A. K., and Khalil, K. I. (2016): Metamorphic and geochronologic constraints on the tectonic evolution of the Central Eastern Desert of Egypt. Precamb. Res., 283:144-168.

El-Wahed, M.A.A. (2008): Thrusting and transpressional shearing in the Pan-African nappe south west ElSibai core complex, Central Eastern Desert, Egypt. J. Afr. Earth Sci., 50(1):16-36.

Fowler, A.-R., Khamees, H., and Dowidar, H. (2007): El Sibai gneissic complex, Central Eastern Desert, Egypt: folded nappes and syn-kinematic gneissic granitoid sheets-not a core complex. J. Afr. Earth Sci., 49(4-5):119-135.

Fritz, H., Abdelsalam, M. M., Ali, K., Bingen, B., Collins, A., Fowler, A., Ghebreab, W., Hauzenberger, C., Johnson, P., and Kusky, T. (2013): Orogen styles in the East African Orogen: are view of the Neoproterozoic to Cambrian tectonic evolution. J. Afr. Earth Sci., 86:65-106.

Fritz, H., Dallmeyer, D. R., Wallbrecher, E., Loizenbauer, J., Hoinkes, G., Ummayr, P.Ne and Khudeir, A.A. (2002): Neoproterozoic tectono thermal evolution of the Central Eastern Desert, Egypt: as low velocity tectonic process of core complex exhumation. J. Afr. Earth Sci., 34(3-4):137-155.

Fritz, H., Wallbrecher, E., Khudeir, A., El Ela, F.A., and Dallmeyer. D. (1996): Formation of Neoproterozoic metamorphic complex during oblique convergence, Eastern Desert, Egypt. J. Afr. Earth Sci., 23(3):311-329.

Hamimi, Z. E. (1988): Geology and structure of Gebel El Hadid area, Eastern Desert, Egypt (Doctoral dissertation, M. Sc. Thesis), Zagazig Univ. 108 pp.

Hamimi, Z., El-Wahed, M. A., Gahlan, H., and Kamh, S. (2019): Tectonics of the Eastern desert of Egypt: Key to understanding the Neo-Proterozoic evolution of the Arabian-Nubian shield (East African Orogen). In The Geology of the Arab World-An Overview, 1-81. Springer.

Kabesh, M. and Refaat. A. (1975): On the chemistry of biotites and variation of ferrous-ferric ratios in the granitic rocks of Umm Naggat stock, Egypt. Neues Jahrb. Miner. Abh, 124:47-60.

Kamal El Din, G. M. (1993): Geochemistry and tectonic significance of the Pan-African El Sibai window, Central Eastern Desert, Egypt. Sci. Ser. Inter. Bureau, For Schungzentrumm Julich, 19, 154.

Liégeois, J. P., and Stern, R. J. (2010): Sr-Nd isotopes and geochemistry of granite-gneiss complexes from the Meatiq and Hafafit domes, Eastern Desert, Egypt: no evidence for pre Neoproterozoic crust. J. Afr. Earth Sci., 57(1-2), 31-40.

Noweir, A., Ghoneim, M., and El-Anwar, M. (1983): Geology and lithostratigraphy of the Pre-Cambrian around Umm Gheig, Eastern Desert, Egypt. Proc. ${ }^{\text {th }}$ Inter. Conf. Basement Tectonics, 77-83.

Ramsay, J. G. (1967): Folding and fracturing of rocks. McGraw Hill Book Company, 568p.

Rogers, J. J. W., and Adams, J. A. S. (1969): Thorium. Handbook of geochemistry, 2(4),1- 90. 


\section{Geological, structural and radioactivity studies of Wadi Sutrah}

Sabet, A. H. A. (1961): Geology and Mineral Deposits of Gebel El Sibai Area, Red Sea Hills, Egypt. Proefschrift, Etc. [With a Map and with SU mmaries in Dutch and Arabic]. Uitgeverij Excelsior.

Stern, R. J. and Hedge, C. E. (1985): Geochronologic and isotopic constraints on Late Pecambrian crustal evolution in the Eastern Desert of Egypt. Am. J. Sci., 285(2):97-127.

Takla, M., Hamimi, Z., Hassanein, S., and Kaoud, N. (1999): Characterization and genesis of the BIF associating arc metavolcanics, Umm Ghamis area, Central Eastern Desert Egypt. Egypt. Mineral., 11:157-185.

Turner, F. and Weiss, J. (1963). Structural analysis of metamorphic tectonites, McGraw-Hill. New York. US. 
Khamees, et al

دراسات جيولوجية وتركيبية وإشعاعية لمنطقة وادى ستره-أم غيج ، وسط الصحراء الثرقية-مصر

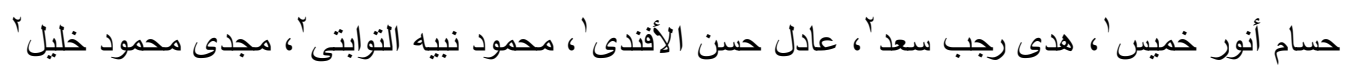

$$
\text { r ق هيئة المواد النووية - القطامية ص.ب . . به المعادى-مصر }
$$

الخلاصة

تقع منطقة وادي ستره-أم غيج في وسط الصحراء الثرقية ، على بعد ·r كم غرب مطار مرسى علم الدولي و .0 كم

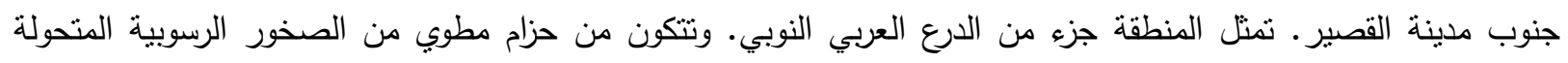

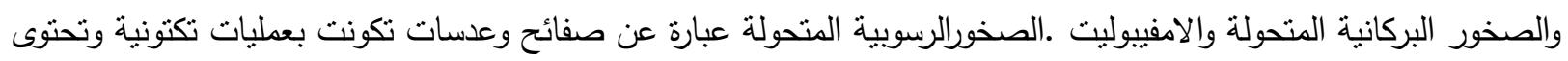

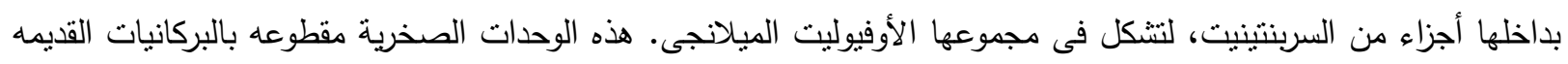

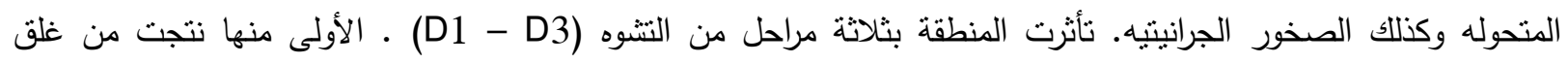
الأحواض المتداخلة بين القوسيه ، وتموضع الأفيوليت المبلانجى أثناء تصادم جنوب وشرق الجندوانا. في منطقة أم غميس ،

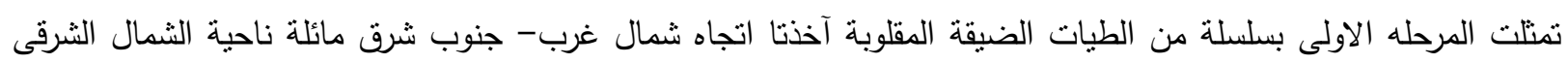

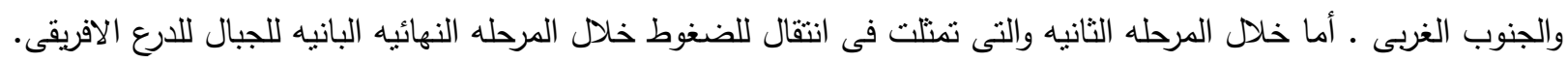

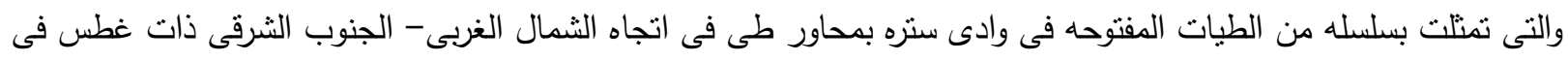

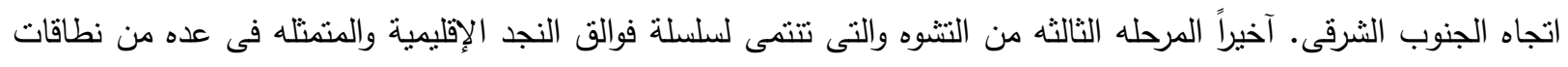

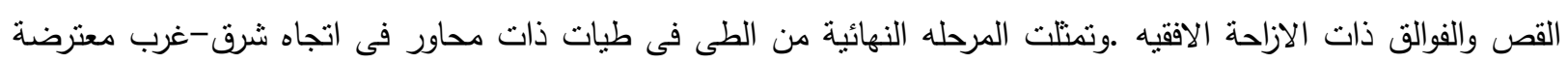
مرحلتى التشوه السابقتين. تعد منطقة الدراسة من المناطق الفقيرة اشعاعيا ما عدا الجزء الثمالي لها والمتمثلنين بكتلتي الجرانيت أم ناقات وكادابورا والتي تعدا من المناطق الغنبة اشعاعبا لاحتوائهما علي نسبة مرتفعة من البورانيوم والثوريوم لكنهما متواجدين في المعادن الحاملة لهما متل معادن الزيركزن والاسفين والاباتيت والكولومبيت والسمارسكيت والثنوريت. 